\title{
Insular species of Afrotropical freshwater crabs (Crustacea: Decapoda: Brachyura: Potamonautidae and Potamidae) with special reference to Madagascar and the Seychelles
}

\author{
Neil Cumberlidge \\ Department of Biology, Northern Michigan University, Marquette, MI 49855-5376, USA, ncumberl@nmu.edu
}

Key words: Freshwater crabs, Afrotropical islands, Madagascar, Seychelles, Socotra

\begin{abstract}
The evolutionary relationships between island and mainland faunas of the 24 species of insular freshwater crabs in the Afrotropical region are reviewed in the light of phylogenetic studies. Twenty insular species of freshwater crabs are endemic, and four are also found on the neighboring mainland of Africa. The Atlantic Ocean islands of Sherbro, Bioko, Príncipe, and São Tomé support five species of Potamonautidae, while the Western Indian Ocean islands of the Seychelles, Zanzibar, Pemba, Mafia, and Madagascar together have 16 species of Potamonautidae, and Socotra has three species of Potamidae. Disjunct distributions of non-endemic insular species of Afrotropical freshwater crabs with conspecifics on the mainland are the result of past lower sea levels that once united islands with the coast. The presence of endemic species of freshwater crabs on oceanic volcanic islands (such as Príncipe and São Tomé) separated from the mainland by deep seas is probably the result of transoceanic dispersal. Endemic genera of freshwater crabs found on oceanic 'Gondwanan' islands are derived from ancestral populations on the Eurasian (Socotra) or African (The Seychelles and Madagascar) mainlands that probably reached there by transoceanic dispersal, rather than their being the vicariant descendents of Gondwanan ancestors. Species of freshwater crabs found on islands in the Afrotropical region are either not unique, or are endemic at the species or genus level. The degree of endemism depends on the island's geological history: whether it is part of the continental shelf, an oceanic island of volcanic origin, or a former part of the ancient continent of Gondwana.
\end{abstract}

\section{Contents}

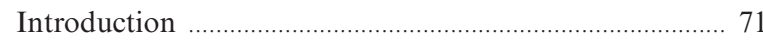

Afrotropical islands with freshwater crabs ....................... 72

Continental islands ........................................................... 73

Sherbro island ………............................................. 73

Bioko ……................................................................. 73

Zanzibar (Unguja), Mafia, and Pembra …................... 74

Oceanic 'Gondwanan' islands .......................................... 75

Socotra ….................................................................... 75

The Seychelles ……....................................................... 75

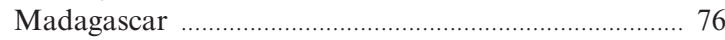

Oceanic volcanic islands ...................................................... 77

Príncipe and São Tomé ..................................................... 77

Transoceanic dispersal by freshwater crabs ...................... 78

Discussion ...................................................................... 79

Acknowledgements ............................................................. 79

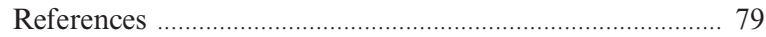

\section{Introduction}

Freshwater crabs (Potamidae, Potamonautidae, Gecarcinucidae, Parathelphusidae, Pseudothelphusidae, Trichodactylidae) are a group of more than 1,280 species that comprises the largest group within the Brachyura according to the latest assessment (Ng et al., 2008). Freshwater crabs have a global distribution that includes not only the tropical and subtropical inland waters of the major continents but also many dozens of islands, some of which (such as the Seychelles and Madagascar) are located considerable distances from the mainland and are separated by deep oceans (Yeo et al., 2008). Monophyly of each of the families of freshwater crabs and continent-wide regional distributions make the freshwater crabs useful subjects for testing dispersalist versus vicariant biogeographic hypotheses because their range was achieved despite their limited ability to disperse long distances overland in their natural habitat. In addition, deserts, high mountain ranges, cold waters, and saltwater habitats are all significant barriers to freshwater crab distribution.

Limits to the dispersal of freshwater crabs within their natural habitats (rivers, streams, marshes, and lakes) arise from their adaptations to life in fresh water that include direct development, a reproductive strategy that lacks all free-living larval stages (Cumberlidge, 1999). Their marine crab relatives have no such limits because they produce thousands of eggs and free-swimming larval stages that are carried over long distances by ocean currents. The life cycle of freshwater crabs therefore 
precludes long-distance dispersal and restricts them to the much more limited excursions made by adults within their habitats in the inland waters of continents (Ng and Rodriguez, 1995). Other factors that limit dispersal by freshwater crabs include the inability of those fully aquatic species that live in major rivers and lakes to move between river basins because they cannot survive for long out of water. Semi-terrestrial species of freshwater crabs are not limited in this way and could potentially migrate between river basins because they can breathe air as well as water and can live out of water for extended periods. However, semi-terrestrial species are limited in their dispersal and choice of habitat by their inability to tolerate prolonged submersion in deep water such as might occur in major rivers and lakes (Rodriguez, 1986). Perhaps the greatest limitation to dispersal by freshwater crabs is the fact that these strictly fresh water crustaceans are saltintolerant and are never found naturally either in sea water or in brackish water (Cumberlidge, 1999). Despite these limitations freshwater crabs are nevertheless found throughout the inland waters of the continents and on numerous tropical islands around the world (Yeo et al., 2008).

\section{Afrotropical islands with freshwater crabs}

The Afrotropical region is dominated by freshwater crabs of the Potamonautidae, a monophyletic family endemic to the Afrotropical region (Daniels et al., 2006; Cumberlidge et al., 2008). Islands in the Afrotropical region with freshwater crabs include those that are nearshore that were recently connected to the mainland, those that are volcanic in origin that rose up from the seabed, and those that were formerly part of the supercontinent of Gondwana. The islands off Africa differ in size, geological age, length of isolation, distance offshore, and depth of seas separating them from the mainland, as well as climate, latitude, landform, soils, and the direction of prevailing winds and currents. As a result island faunas and floras tend to be diverse and have high rates of endemism, especially large islands such as Madagascar that have been isolated for millions of years. Not all of Africa's islands have been colonized by species of freshwater crabs, but those that have possess a consistently warm and stable tropical climate.

Afrotropical freshwater crabs are found on sev- eral islands in the Western Indian Ocean (Socotra, Seychelles, Zanzibar, Pemba, Mafia, and Madagascar) and comprise three species of Potamidae and 16 species of Potamonautidae. Another five species of Potamonautidae are found on West African islands in the Atlantic Ocean (Sherbro, Bioko, Príncipe, and São Tomé). A total of 20 insular species in the Afrotropical region are endemic, while four are also found on the neighboring mainland of Africa (Fig. 1, Table 1).

Socotra has three species, Socotra pseudocardisoma (Cumberlidge and Wranik, 2002), Socotrapotamon socotrensis (Rathbun, 1904), and S. nojidensis Apel and Brandis, 2000 (Potamidae: Potaminae). The granitic islands in the Seychelles host one species, Seychellum alluaudi (Bouvier, 1898) (Potamonautidae: Deckeniinae), and Zanzibar, Pemba, and Mafia host one species, Potamonautes obesus (A. MilneEdwards, 1868) (Potamonautidae: Potamonautinae). The largest island in the Western Indian Ocean, Madagascar, has the most diverse freshwater crab fauna comprising 14 species of potamonautids $(\mathrm{Ng}$ and Takeda, 1994; Cumberlidge et al., 2002; Cumberlidge and Sternberg, 2002; Cumberlidge et al., 2004; Reed and Cumberlidge, 2006a; Daniels et al., 2006; Cumberlidge et al., 2008). The Atlantic Ocean side of Africa has insular species of potamonautine Afrotropical freshwater crabs on Bioko (Sudanonautes granulatus (Balss, 1929) and S. floweri (de Man, 1901)), Príncipe (Potamonautes principe (Cumberlidge, Clark and Baillie, 2002), and São Tomé ( $P$. margaritarius (Rathbun, 1904)). In addition, Sherbro Island near the coast of Sierra Leone is home to one species, Afrithelphusa leonensis (Cumberlidge, 1987) (Potamonautidae: Deckeniinae).

Freshwater crabs are absent from the Cape Verde Islands, Annobon (Pagalu), the coralline Seychelles, the Comoros, Inacha, Mauritius, Rodrigues, and Réunion. The absence of freshwater crabs from Afrotropical islands can best be understood in terms of the island's size, age, and distance from the mainland. Most of the islands that lack freshwater crabs were never connected to the mainland and are either coralline or volcanic in origin; none are ancient fragments of Gondwana. For example, the volcanic island of Annobon (Equatorial Guinea) is $350 \mathrm{~km}$ offshore, small (only $17 \mathrm{~km}^{2}$ ), and young (4.8 My old). Similarly, the three remote islands in the colder South Atlantic (Tristan da Cunha, St. Helena, and Ascension) are all extremely far 


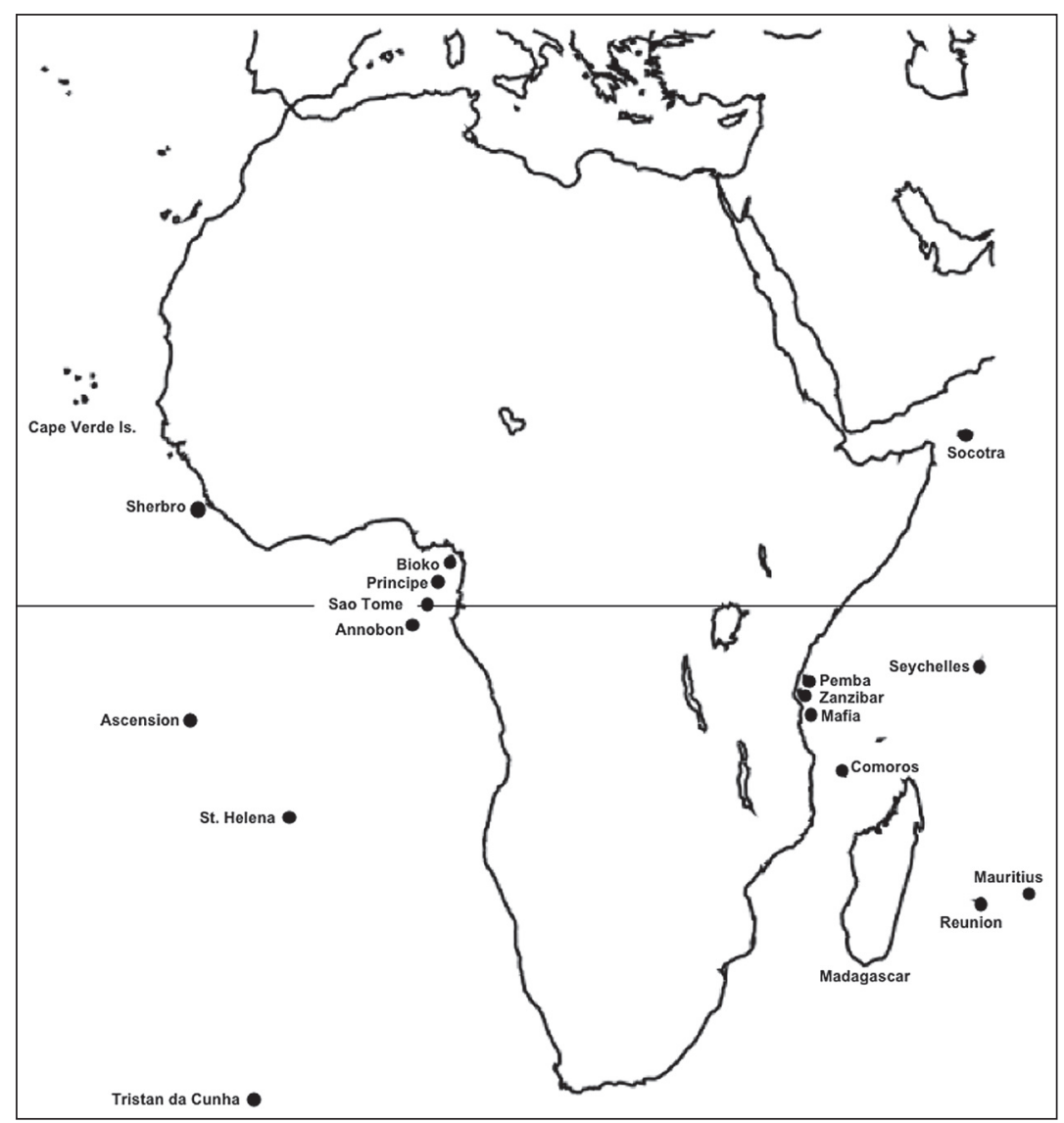

Fig. 1. Map showing the major islands in the Afrotropical region. from the mainland, small in size, and surrounded by cold seas.

\section{Continental islands}

Freshwater crabs that occur on nearshore (continental shelf) islands that are separated from the mainland by relatively shallow seas are assumed to have reached there in the past (either in the Tertiary or Quaternary) at times when sea levels were more than $100 \mathrm{~m}$ lower than today, thereby uniting today's islands with the mainland. In such cases, there is no requirement for freshwater crabs to have crossed a sea water barrier to reach an island.

\section{Sherbro island}

Sherbro island $\left(670 \mathrm{~km}^{2}\right)$ (Sierra Leone) lies in the Atlantic Ocean $8 \mathrm{~km}$ off the coast of West Africa, and is separated from the mainland by the shal- low waters of the Sherbro Strait. The disjunct distribution of the potamonautid freshwater crab Afrithelphusa leonensis on Sherbro island and on the nearby mainland in Sierra Leone undoubtedly reflects a relatively recent isolation event of this continental shelf island that can be attributed to past changes in sea level (Cumberlidge 1987, 1999).

\section{Bioko}

Bioko $\left(2,017 \mathrm{~km}^{2}\right)$ (Equatorial Guinea) is located in the Gulf of Guinea about $40 \mathrm{~km}$ from Cameroon, $100 \mathrm{~km}$ from southern Nigeria and $160 \mathrm{~km}$ northwest of continental Equatorial Guinea. This volcanic island has forested mountains $(3,308 \mathrm{~m}$ asl), a recent history of connection to the mainland, and supports two species of freshwater crabs, Sudanonautes floweri and S. granulatus, neither of which is endemic (Cumberlidge, 1993, 1995, 1999). Today both of these species are distributed over a wide area of West and Central Africa that includes 
Table 1. The major islands in the Afrotropical region and their freshwater crab fauna.

$*$ endemic species; $* *=$ endemic genus; $\#$ sp. $=$ number of species.

\begin{tabular}{|c|c|c|c|c|c|c|}
\hline Island & $\begin{array}{l}\text { Origin } \\
\text { Island }\end{array}$ & $\begin{array}{l}\mathrm{km}^{2} \\
\text { Area }\end{array}$ & $\begin{array}{l}\mathrm{km} \\
\text { Distance }\end{array}$ & \multicolumn{2}{|c|}{ \# sp. Family } & Genus and Species \\
\hline Madagascar & Gondwanan & 590,000 & 400 & $14^{* *}$ & Potamonautidae & Boreas uglowi \\
\hline Madagascar & Gondwanan & 590,000 & 400 & & Potamonautidae & Foza raimundi \\
\hline Madagascar & Gondwanan & 590,000 & 400 & & Potamonautidae & Hydrothelphusa agilis \\
\hline Madagascar & Gondwanan & 590,000 & 400 & & Potamonautidae & Hydrothelphusa bombetokensis \\
\hline Madagascar & Gondwanan & 590,000 & 400 & & Potamonautidae & Hydrothelphusa goudoti \\
\hline Madagascar & Gondwanan & 590,000 & 400 & & Potamonautidae & Hydrothelphusa madagascariensis \\
\hline Madagascar & Gondwanan & 590,000 & 400 & & Potamonautidae & Hydrothelphusa vencesi \\
\hline Madagascar & Gondwanan & 590,000 & 400 & & Potamonautidae & Madagapotamon humberti \\
\hline Madagascar & Gondwanan & 590,000 & 400 & & Potamonautidae & Malagasya antongilensis \\
\hline Madagascar & Gondwanan & 590,000 & 400 & & Potamonautidae & Malagasya goodmani \\
\hline Madagascar & Gondwanan & 590,000 & 400 & & Potamonautidae & Marojejy longimerus \\
\hline Madagascar & Gondwanan & 590,000 & 400 & & Potamonautidae & Skelosophusa eumeces \\
\hline Madagascar & Gondwanan & 590,000 & 400 & & Potamonautidae & Skelosophusa gollhardi \\
\hline Madagascar & Gondwanan & 590,000 & 400 & & Potamonautidae & Skelosophusa prolixa \\
\hline Seychelles & Gondwanan & 454 & $480-1600$ & $1 * *$ & Potamonautidae & Seychellum alluaudi \\
\hline Socotra & Gondwanan & 3625 & 400 & $3^{*}$ & Potamidae & Socotra pseudocardisoma \\
\hline Socotra & Gondwanan & 3625 & 400 & & Potamidae & Socotrapotamon socotrensis \\
\hline Socotra & Gondwanan & 3625 & 400 & & Potamidae & Socotrapotamon nojiensis \\
\hline Zanzibar & Continental & 1660 & 35 & 1 & Potamonautidae & Potamonautes obesus \\
\hline Mafia & Continental & 394 & 48 & 1 & Potamonautidae & Potamonautes obesus \\
\hline Pemba & Continental & 984 & 56 & 1 & Potamonautidae & Potamonautes obesus \\
\hline Bioko & Continental & 2017 & 40 & 2 & Potamonautidae & Sudanonautes granulatus \\
\hline Bioko & Volcanic & 2017 & 40 & & Potamonautidae & Sudanonautes floweri \\
\hline Principe & Volcanic & 128 & 250 & $1^{*}$ & Potamonautidae & Potamonautes principe \\
\hline Sao Tome & Volcanic & 836 & 300 & $1 *$ & Potamonautidae & Potamonautes margaritarius \\
\hline Sherbro & Continental & 670 & 8 & 1 & Potamonautidae & Afrithelphusa leonensis \\
\hline Rodrigues & Volcanic & 108 & 1900 & 0 & No FWC & No FWC \\
\hline Réunion & Volcanic & 5500 & 1500 & 0 & No FWC & No FWC \\
\hline Cape Verde Is. & Volcanic & 4000 & 500 & 0 & No FWC & No FWC \\
\hline Mauritius & Volcanic & 1865 & 1900 & 0 & No FWC & No FWC \\
\hline Comoros & Volcanic & 1862 & 500 & 0 & No FWC & No FWC \\
\hline Tristan da Cunha & Volcanic & 201 & 2816 & 0 & No FWC & No FWC \\
\hline Aldabra & Volcanic & 155 & 600 & 0 & No FWC & No FWC \\
\hline St. Helena & Volcanic & 122 & 2720 & 0 & No FWC & No FWC \\
\hline Ascension & Volcanic & 90 & 1700 & 0 & No FWC & No FWC \\
\hline Annobon & Volcanic & 17 & 350 & 0 & No FWC & No FWC \\
\hline
\end{tabular}

the neighboring lowland coastal regions of Nigeria, Cameroon, Equatorial Guinea and Gabon (Cumberlidge 1999). These two species may have reached Bioko overland at a time when sea levels were lower and this island was united with the mainland.

\section{Zanzibar (Unguja), Mafia, and Pemba}

A single species of potamonautid, Potamonautes obesus, is found on the islands of Zanzibar, Mafia, and Pemba (Tanzania) and across a wide area of East Africa that includes the lowland coastal re- gions of Somalia, Kenya, Tanzania, and Mozambique (Reed and Cumberlidge, 2006b). Zanzibar $\left(1,660 \mathrm{~km}^{2}\right)$ and Mafia $\left(394 \mathrm{~km}^{2}\right)$ are nearshore continental shelf islands that lie $35 \mathrm{~km}$ and $48 \mathrm{~km}$ respectively from the coast of Tanzania. Today they are separated by shallow seas but in the recent past they were connected to the mainland of Africa (50,000 years ago and again 10,000 years ago) (Kingdon, 1989). It is likely that the ancestors of $P$. obesus may have reached Zanzibar and Mafia at a time when low sea levels permitted overland dispersal. Pemba $\left(984 \mathrm{~km}^{2}\right)$ the third of the Tanzanian spice islands, is located $56 \mathrm{~km}$ off the coast and is 
much older than the other Tanzanian islands, dating back to the Miocene; it is separated from the mainland continental shelf by an $800 \mathrm{~m}$ deep trench that is at least several million years old (Kingdon, 1989). The presence of P. obesus on Pemba (which would not have been connected to the mainland even in the Tertiary or Quaternary when sea levels were much lower than they are today) suggests possible transoceanic dispersal to this island perhaps by natural rafts.

\section{Oceanic 'Gondwanan' islands}

There is disagreement about the origins of freshwater crabs on oceanic islands that were once part of Gondwana. Some authors have ruled out overseas colonization because saltwater has long been assumed to be an effective barrier to dispersal by freshwater crabs, and instead have proposed hypotheses that favored Gondwanan ancestry made disjunct today by Mid-Cretaceous vicariant events associated with continental break-up (Rodriguez, 1986; Ng et al., 1995; Ng and Rodriguez, 1995). The long-held assumptions of Gondwanan ancestry and Indian affinities for freshwater crabs found on the Seychelles and Madagascar have been challenged recently by the molecular phylogenic study of Daniels et al. (2006) that included genera from Africa, Madagascar, the Seychelles, India and Socotra (Cumberlidge et al., 2008). This study, and that of Klaus et al. (2006), gave new insights into the relationships of the Afrotropical freshwater crabs found on the islands in the Indian Ocean. In addition, Daniels et al. (2006) provided new estimates of divergence times that were not congruent with the geological history of this part of Gondwana (whereby Madagascar-Seychelles-India split from Africa in the Mid-Cretaceous over 160 Mya) (Rabinowitz et al., 1983). In summary, the majority of available evidence supports hypotheses that insular species of freshwater crabs on oceanic islands in the Afrotropical region reached their present distribution by transoceanic dispersal rather than vicariance (Daniels et al., 2006; Cumberlidge et al., 2008).

\section{Socotra}

Socotra $\left(3,625 \mathrm{~km}^{2}\right)$ (Republic of Yemen) lies in the Western Indian Ocean $350 \mathrm{~km}$ south of the Arabian peninsula, $400 \mathrm{~km}$ east of Somalia, and 1,600 km north of the Seychelles and is separated from nearby landmasses by deep seas. The Socotra archipelago comprises the main island and three smaller islands, and has mountains that reach $1,525 \mathrm{~m}$ asl. Socotra is an African Gondwanan continental fragment that is part of the Afrotropical region, and has experienced a long period of geological isolation. Socotra's fauna and flora are generally more closely linked with Africa than with the Arabian peninsula, but this is not the case for the island's endemic freshwater crab fauna which have Palaearctic rather than Afrotropical affinities (Daniels et al., 2006; Cumberlidge et al., 2008). Interestingly, the two potamid genera found on Socotra are not part of the main African potamonautid freshwater crab radiation and morphological studies place their affinities with the Palaearctic and Oriental Potaminae (Apel and Brandis, 2000; Cumberlidge and Wranik, 2002; Yeo and $\mathrm{Ng}$, 2003). Interestingly, the molecular study of Daniels et al. (2006) contradicts this assumption, and positions Socotra close to Johora tiomanensis ( $\mathrm{Ng}$ and Tan, 1984) from Palau Tioman, Malaysia and Geothelphusa albogilva (Shy, Ng and Yu, 1994) from Taiwan (both Potamiscinae). The presence on Socotra of three endemic species and two endemic genera of potamid freshwater crabs (Socotra pseudocardisoma, Socotrapotamon socotrensis, and S. nojidensis) that belong to a Eurasian family is most likely the result of dispersal to the island either from the Middle East (if Potaminae) or from southeast Asia (if Potamiscinae). Overseas rafting is a possible route of transportation to Socotra from either one of these mainland centers, while Apel and Brandis (2000) have argued for overland dispersal via the Middle East to Socotra at a time when the region was much less arid.

\section{The Seychelles}

The Seychelles are a group of more than a hundred granitic and coralline islands, cays, and atolls in the Indian Ocean that extend between 160 and 1,300 $\mathrm{km}$ north of Madagascar, 480 and 1,600 km east of Africa (Tanzania, Kenya, and Somalia), and some $3,000 \mathrm{~km}$ from India. The long isolation of the Seychelles (75 million years) and the great distance from the mainland has resulted in a highly endemic flora and fauna that includes Seychellum alluaudi a morphologically unique genus and species of freshwater crab ( $\mathrm{Ng}$ et al., 1995). This species is found only on the four largest granitic Gondwanan islands 
(Mahé, Praslin, Silhouette and La Digue) (with a combined area of only $454 \mathrm{~km}^{2}$ ) that lie $1,600 \mathrm{~km}$ off the coast of Africa, and it is absent from the more recent but still isolated coralline Seychelles islands ( $\mathrm{Ng}$ et al., 1995). The presence of the same species of freshwater crab on these four remote islands in the Seychelles is probably the result of their more recent isolation from each other by present day high sea levels. Until recently, the granitic Seychelles consisted of a much larger Gondwanan landmass $\left(55,000 \mathrm{~km}^{2}\right)$ known as the Seychelles Bank, when past sea levels were more than $100 \mathrm{~m}$ lower than at present. Today most of this land is submerged and only the terrestrial communities on the hilltops (where Seychellum is found) survived, presumably because the higher elevations remained above the surface when the oceans rose to their present levels.

How Seychellum came to be on the Seychelles in the first place has been the subject of disagreement over the years. Authors that discount the possibility of oceanic dispersal by freshwater crabs (Rodriguez, 1986; Ng et al., 1995; Ng and Rodriguez, 1995) have explained the presence of these decapods on the Seychelles by simple vicariance, arguing that freshwater crab ancestors already lived on this part of Gondwana before it fragmented. On the other hand, the morphological and molecular evidence that can now be brought to bear over the question of the origins of Seychellum favors accidental overseas dispersal over vicariance (Daniels et al., 2006; Cumberlidge et al., 2008). For example, the closest affinities of Seychellum are with ancestral East African Deckeniinae rather than with African Potamonautinae or Indian Gecarcinucidae (Daniels et al., 2006; Klaus et al., 2006; Cumberlidge et al., 2008). The phylogenetic relationships between Seychellian freshwater crabs and those from Madagascar, Afri$\mathrm{ca}$, and India therefore do not fit the temporal framework of Gondwanan fragmentation in the Mesozoic whereby Madagascar-Seychelles-India split first from Africa, followed millions of years later by the break-up of the Seychelles and India. In addition, the divergence time estimates for the Afrotropical clade (78.6-75.03 Mya), the Seychellum/Deckenia clade (75 Mya), and the Malagasy clade (43.5-39 Mya) indicate Upper/Late Cretaceous or Eocene origins for these lineages (Daniels et al., 2006) that are not congruent with the dates for continental break-up. The fact that Seychellum and Deckenia (East Africa) today occur on opposite sides of a deep oceanic barrier argues for overseas dispersal rather than vicariance. The common ancestor of these two genera was presumably living on the African mainland (where Deckenia still occurs) (rather than Madagascar or India) and was carried to the Seychelles by accidental transoceanic dispersal. The distance between the coast of Africa and the granitic Seychelles today is about $1,600 \mathrm{~km}$, but this would have been considerably shorter in the Upper/ Late Cretaceous.

\section{Madagascar}

Madagascar $\left(590,000 \mathrm{~km}^{2}\right)$ today lies about $400 \mathrm{~km}$ from the east coast of southern Africa (Mozambique) and became separated from Africa 165-121 Myr ago and from the Seychelles and India 88-63 Myr ago (Rabinowitz et al., 1983; Storey et al., 1995). The long period of isolation of Madagascar's original Gondwanan fauna together with additions by dispersal events over the years have produced a unique endemism on this island that includes an impressive number of species of freshwater crabs. The seven endemic genera and fourteen endemic species of Malagasy freshwater crabs are unevenly distributed on the island and are most diverse in Antsiranana Province in northern Madagascar, an area with both dry and moist forests that includes the Tsaratanana and Marojejy mountains ( $\mathrm{Ng}$ and Takeda, 1994; Cumberlidge and Sternberg, 2002; Cumberlidge et al., 2004; Cumberlidge et al., 2005; Reed and Cumberlidge, 2006a; Daniels et al., 2006; Cumberlidge et al., 2008). The tropical rainforest on the mountainous eastern side of the island has a lower freshwater crab species diversity, while crabs are completely absent from vast areas the island on the western side (where the vegetation consists of dry deciduous forests) and in the far south (which is arid spiny desert) (Cumberlidge et al., 2004).

The fourteen species of Malagasy freshwater crabs are so striking in their morphological variety that they have been assigned to seven genera (Cumberlidge et al., 2000; Cumberlidge and Sternberg, 2002; Reed and Cumberlidge, 2006a; Cumberlidge et al., 2008). They are also sufficiently morphologically divergent from the freshwater crab fauna elsewhere in the Afrotropical region to have been assigned to two different families by some authors (Bott, 1960, 1965, 1969a, 1970a; Ng et al., 1995). These authors argued that the Malagasy freshwater crabs comprised two separate lineages, one group 
with supposedly African affinities that they placed in the Potamonautidae, and the other group with supposedly Indian and Seychellian (Gondwanan) affinities that they placed in the Gecarcinucidae. This arrangement meshed with the view that it was the fragmentation of the Gondwanan supercontinent that carried the freshwater crabs to their present position on Madagascar and not transoceanic rafting (Bott, 1960, 1965; Ng et al., 1995; Ng and Rodriguez, 1995). Vicariance hypotheses require that freshwater crabs found on Gondwanan continental fragments have phylogenetic relationships that are congruent with a shared history of continental break-up. However, this two-family hypothesis for the Malagasy freshwater crabs was not supported by the morphological study of Cumberlidge and Sternberg (2002), or by the molecular study of Daniels et al. (2006), which both concluded that all Malagasy taxa form a single monophyletic lineage that was part of the African Potamonautidae (Cumberlidge et al., 2008). Daniels et al. (2006) identified the sister group of the Malagasy freshwater crabs to be a clade consisting entirely of African genera that were included in the African Potamonautidae by Cumberlidge and Sternberg (2002) and Cumberlidge et al. (2008). The consensus phylogeny (based on molecular and morphological evidence) is not congruent with the affinities predicted by Gondwanan breakup, and supports African origins for the Malagasy freshwater crabs (Daniels et al., 2006; Cumberlidge et al., 2008). In addition, the molecular divergence estimates provided by Daniels et al. (2006) indicated that the Malagasy freshwater crabs diverged from their African relatives about 43.5-39 Mya, long after the separation of Madagascar from Africa. The available data indicate that the Malagasy freshwater crabs most likely descended from a transoceanic migrant from Africa during the Eocene (Palaeogene) when the distance between the coast of Africa and northwest Madagascar would have been considerably shorter than it is today $(400 \mathrm{~km})$.

Klaus et al. (2006) also proposed that freshwater crabs reached Madagascar and the Seychelles from Africa in the past by rafting across oceanic distances that were shorter than today, but they differed in their estimates of the timing of this event and in the way it may have happened. Klaus et al. (2006) argued that freshwater crabs reached these islands during the Oligocene 28 Mya when sea levels were 150-200 $\mathrm{m}$ lower than today and when significant portions of the continental shelves as well as the
Mascarene Plateau, Seychelles Bank, and Chagos/ Laccadive Plateau were emergent. Klaus et al. (2006) also suggested that freshwater crabs may have reached Madagascar and the Seychelles from Africa indirectly by rafting via intervening small emergent islands and seamounts that served as 'stepping stones'. Those authors further suggested that freshwater crabs in the Seychelles reached India via the Chagos/Laccadive Plateau during the Oligocene but this is considered unlikely here because Daniels et al. (2006) found no close relationship between any Afrotropical genera (Potamonautidae) and Indian and southeast Asian genera (representing the Gecarcinucidae and Parathelphusidae).

\section{Oceanic volcanic islands}

While there is more than one explanation (overseas dispersal or vicariant origins) for how freshwater crabs came to be on oceanic 'Gondwanan' islands, there is little debate about the presence of freshwater crabs on oceanic volcanic islands: it is assumed that crabs reached there by overseas dispersal. However, it would seem that large stretches of saltwater present a formidable, but not entirely impenetrable, barrier to freshwater crab dispersal.

\section{Príncipe and São Tomé}

The volcanic islands of Príncipe $\left(128 \mathrm{~km}^{2}\right)$ and São Tomé $\left(836 \mathrm{~km}^{2}\right)$ (São Tomé and Príncipe) lie 250 $\mathrm{km}$ and $300 \mathrm{~km}$ from the mainland and both have forested mountains that reach 948 and 2,024 m asl respectively. Príncipe rose out of the sea about 31 Mya (Oligocene), while São Tomé dates back to about 14 Mya (Miocene). The presence of an endemic species of potamonautid freshwater crab on each of these islands (Potamonautes principe on Príncipe, and Potamonautes margaritarius on São Tomé) means that each species is the product of a separate dispersal event from the mainland, presumably by natural rafts. Colonization of each island separately is the most likely because there is no morphological evidence that these species are closely related to each other and therefore no reason to assume that there was any island-to-island transfer (the distance between the closest islands is $146 \mathrm{~km}$ ). While both taxa are endemic at the species level, the genus is distributed widely not only in the nearby coastal countries but also throughout sub-Saharan 
Africa (Cumberlidge, 1999; Cumberlidge et al., 2002). Measey et al. (2007) have recently proposed that amphibians and other salt-intolerant animals found on oceanic islands in the Gulf of Guinea reached there by rafting aided by favorable surface currents and by surface waters of reduced salinity (rather than by storms, birds, or rafts alone). Those authors argued that low-salinity 'freshwater paths' in the surface layers of the ocean (formed either by catastrophic events or by wet periods in climatic history) lasted long enough to be capable of transporting salt-intolerant continental animals to isolated oceanic islands.

\section{Transoceanic dispersal by freshwater crabs}

It would seem that oceanic dispersal, rather than Gondwanan break-up and a simple vicariant history, produced present-day freshwater crab distributions on the three oceanic 'Gondwanan' islands in the Western Indian Ocean, and on the two volcanic islands in the Atlantic considered here. Island colonization preceded by accidental transoceanic dispersal of freshwater crabs to oceanic islands requires that these strictly freshwater decapods survive both periods of submergence in sea water and exposure out of water for two or more weeks. The fact that freshwater crabs are salt-intolerant and are never found naturally in saltwater habitats argues for their accidental displacement perhaps during storms violent enough to dislodge large masses of vegetation that would be carried down rivers and out to sea. Transoceanic dispersal would also require favorable ocean currents, and successful colonization on arrival would require the ability to establish viable populations in the freshwater ecosystems of the new island habitat.

A number of authors have offered their opinions on the physiological resistance of freshwater crabs to high salinity, and have concluded that in general gecarcinucoids are salt tolerant but that potamoids are not (Bott, 1969b, 1970b; Haig, 1984; Klauss et al., 2006; Yeo et al., 2008). However, there have been only a few actual studies on the physiological response of freshwater crabs to salt water and their survival times in different salinities, and those that are available contradict the above opinions. For example, experiments on species of Potamoidea from Africa and Europe demonstrated that freshwater crabs do indeed have the ability to osmoregulate in brackish and full strength sea water, and that they can survive for between one to two weeks (Shaw, 1958a, b; Morris and Van Aardt, 1998). The recent comparative study of groups of potamids and parathelphusids from Thailand exposed to sea water for different periods of time found no major differences between these families in either survival time or osmoregulatory ability (Esser, 2007; Esser and Cumberlidge, in prep.).

Esser (2007) and Esser and Cumberlidge (in prep.) found that potamid and parathelphusid freshwater crabs are indeed capable of short-term survival for at least two weeks when exposed to sea water, which would be long enough to survive a short oceanic journey clinging to drifting vegetation. Indeed, many species of African freshwater crabs are semi-terrestrial, have well developed air-breathing capabilities, are resistant to desiccation, and do not require permanent submergence in fresh water (Cumberlidge, 1986, 1991, 1999). This is especially true for the majority of Deckeniinae that includes Deckenia, Seychellum, Afrithelphusa, and Globonautes plus the Malagasy genera, all of which have pseudolungs (Cumberlidge and Sternberg, 2002; Cumberlidge et al., 2008). If adequately protected against desiccation, these animals are at least potentially capable of surviving for the relatively long periods away from fresh water involved in crossing distances of up to $500 \mathrm{~km}$ (Cumberlidge, 1986, 1991, 1999). A single ovigerous female freshwater crab landing on an island with freshwater ecosystems available would potentially be able to ensure a viable number of males and female offspring needed for successful colonization. This is because she typically carries between 200 and 500 fertilized eggs in her abdominal brood pouch, and because each egg eventually releases a hatchling crab without producing any of the freeliving larval stages seen in marine crabs.

Transoceanic dispersal by rafting should be viewed as a rare and accidental occurrence in animals that avoid prolonged contact with sea water, despite the physiological ability of freshwater crabs to be able to withstand periods spent drifting on the open ocean clinging to vegetation, and then to be able to successfully colonize the new island habitat. Overseas dispersal by rafting has also been has been proposed to explain the origins of a range of vertebrates (amphibians, reptiles, and mammals) currently found on the Seychelles and Madagascar (Raxworthy, 2002; Vences et al., 2003, 2004; Yoder et al., 2003; Poux et al., 2005; Yoder and Nowak, 2006). 


\section{Discussion}

The origins of species of freshwater crabs found on continental and oceanic islands elsewhere in the world, such as the Neotropics (Rodriguez and López, 2003) and southeast Asia (Brandis, 2002), are comparable to the findings presented here for the Afrotropical region. For example, one species of Trichodactylidae (Dilocarcinus dentatus (Randall, 1839)) from Trinidad and four species of Pseudothelphusidae are present on continental islands in three areas of Central and South America (Rodriguez and López, 2003). The disjunct distributions of widespread species such as Eudaniela garmani (Rathbun, 1898) on Trinidad and Margarita Island as well as the Venezuelan mainland have been attributed to lower sea levels during the Pleistocene that united these islands with the coast. Similarly, the presence of the endemic species Microthelphusa odaelkae (Bott, 1970c) on Trinidad, and the endemic Potamocarcinus roatanensis on Roatan Island off the coast of Honduras have been attributed to prior land access during lowered sea levels in the Tertiary followed by isolation when sea levels returned to higher levels.

Six endemic species of pseudothelphusids are found on oceanic islands in the Caribbean (five species of Epilobocera on Cuba, Hispaniola, Puerto Rico, and La Croix) (Rodriguez and Williams, 1995), and Guinotia dentata (Latreille, 1828) in the Lesser Antilles islands of Guadeloupe, Dominica, Martinique, St. Lucia and St. Vincent (Rodriguez and López, 2003). Rodriguez (1986) viewed the presence of crabs on these oceanic islands to be the result of a primitive Gondwanan distribution made disjunct by Mid-Cretaceous vicariant events associated with continental break-up. Finally, the presence of the endemic Hypolobocera gorgonensis von Prahl (1983) on Gorgona island off the Pacific coast of Colombia has been attributed to accidental dispersal through natural rafts because the island is separated from the mainland by a channel that is 200 to $1,000 \mathrm{~m}$ deep, which precludes a connection during minimal sea levels in the Quaternary (Rodriguez and López, 2003).

In southeast Asia the distribution patterns of species of Potamidae found on major continental islands of the Sunda shelf (e.g., Sumatra, Java, Borneo, the Philippines, Okinawa, Hainan) are thought to reflect the palaeogeographic and palaeoclimatic conditions of this region during the Tertiary and
Quaternary at times when low sea levels created land bridges between islands (Brandis, 2002). Similar conclusions were reached to explain the distribution patterns of species of potamid freshwater crabs found on islands in the Mediterranean (Brandis et al., 2000).

In conclusion, species of freshwater crabs found on islands in the Afrotropical region (and elsewhere in the world) are either not unique, or are endemic at either the species or genus level. This in turn depends on the island's geological history: whether it is part of the continental shelf, an oceanic island of volcanic origin, or a former part of the ancient continent of Gondwana.

\section{Acknowledgements}

Appreciation is extended to Drs. Vincent Nijman and Ronald Vonk for organizing the symposium and for their kind invitation to contribute to this event. Valuable comments were given by Dr. Miguel Vences and an anonymous reviewer.

\section{References}

Apel M, Brandis D. 2000. A new species of freshwater crab (Crustacea: Brachyura: Potamidae) from Socotra Island and description of Socotrapotamon n. gen. Fauna Arabia 18: $133-144$

Balss H. 1929. Crustacea V. Potamonidae. In: Monod Th., Contributions à l'étude de la faune du Cameroun. Faune des Colonies françaises. Paris 3: 115-129.

Bott R. 1960. Crustacea (Decapoda): Potamonidae. In: Hanstrom B, Brinck P, Ruderbeck G, eds., South African animal life: results of the Lund University expedition in 1950-1951. Uppsala: Almqvist and Wiksells 7: 13-18.

Bott R. 1965. Die Süßwasserkrabben von Madagaskar. Bulletin Du Muséum National d'Histoire Naturelle, Paris 37: 335-350.

Bott R. 1969a. Die Flußkrabben aus Asien und ihre Klassifikation. Senckenbergiana Biologia 50: 339-366.

Bott R. 1969b. Präadaption, Evolution und Besiedlungsgeschichte der Süßwasserkrabben der Erde. Natur und $M u$ seum (Frankfurt am Main) 99: 266-275.

Bott R. 1970a. Betrachtungen über die Entwicklungsgeschichte und Verbreitung der Süßwasser-Krabben nach der Sammlung des Naturhistorischen Museums in Genf/ Schweiz. Revue Suisse de Zoologie 77: 327-344.

Bott R. 1970b. Die Süßwasserkrabben von Europa, Asien, Australien und ihre Stammesgeschichte. Abhandlungen der Senckenbergischen Naturforschenden Gesellschaft 526: $1-33$.

Bott R. 1970c. Bemerkungen zu einigen Süßwasserkrabben (Crustacea, Decapoda). Senckenbergiana Biologia 51: 35.

Brandis D. 2002. On the taxonomic status and biogeography of the Isolapotamidae Bott, 1970 (Decapoda, Brachyura). Journal of Natural History 36: 1291-1339. 
Brandis D, Storch V, Türkay M. 2000. Taxonomy and zoogeography of the freshwater crabs of Europe, North Afri$\mathrm{ca}$, and the Middle East (Crustacea, Decapoda, Potamidae). Senckenbergiana Biologia 80: 5-56.

Cumberlidge N. 1986. Ventilation of the branchial chambers in the amphibious West African fresh-water crab Sudanonautes (Convexonautes) aubryi monodi (Balss, 1929) (Brachyura, Potamonautidae). Hydrobiologia 134: 53-65.

Cumberlidge N. 1987. Notes on the taxonomy of West African gecarcinucids of the genus Globonautes (Brachyura, Decapoda). Canadian Journal of Zoology 65: 2210-2215.

Cumberlidge N. 1991. The respiratory system of Globonautes macropus (Rathbun 1898), a terrestrial freshwater crab from Liberia (Parathelphusoidea, Gecarcinucidae). Crustaceana 61: 69-80.

Cumberlidge N. 1993. Redescription of Sudanonautes granulatus (Balss, 1929) (Potamoidea, Potamonautidae) from West Africa. Journal of Crustacean Biology 113 (4): 805-816.

Cumberlidge N. 1995. Redescription of Sudanonautes floweri (de Man, 1901) (Brachyura: Potamoidea: Potamonautidae) from Nigeria and Central Africa. Bulletin of the British Museum of Natural History (Zoology), London 61: 111-119.

Cumberlidge N. 1999. The freshwater crabs of West Africa. family Potamonautidae. Collection Faune et Flore Tropicales 35, 1-382, IRD, Paris.

Cumberlidge N, Bokyo CB, Harvey AW. 2000. A new genus and species of freshwater crab (Crustacea, Decapoda, Potamoidea) from northern Madagascar, and a second new species associated with Pandanus leaf axils. Journal of Natural History 36: 65-77.

Cumberlidge N, Sternberg Rv. 2002. The freshwater crabs of Madagascar (Crustacea, Decapoda, Potamoidea). Zoosystema 24: 41-79.

Cumberlidge N, Wranik W. 2002. A new genus and new species of freshwater crab (Potamoidea: Potamidae) from Socotra Island, Yemen. Journal of Natural History 36: 51-64.

Cumberlidge N, Clark PF, Baillie J. 2002. A new species of freshwater crab (Brachyura: Potamoidea: Potamonautidae) from Príncipe, Gulf of Guinea, Central Africa. Bulletin of the British Museum of Natural History (Zoology), London 68: 13-18.

Cumberlidge N, Reed SK, Boyko CB. 2004. Distribution patterns of the Malagasy freshwater crabs (Crustacea, Decapoda, Brachyura). Journal of Natural History 38: 1133-1157.

Cumberlidge N, Sternberg Rv., Daniels SR. 2008. A revision of the higher taxonomy of the Afrotropical freshwater crabs (Decapoda: Brachyura) with a discussion of their biogeography. Biological Journal of the Linnean Society 93 (2): 399-413.

Cumberlidge N, Fenolio, DB, Walvoord, ME, Stout J. 2005. Tree-climbing crabs (Potamonautidae and Sesarmidae) from phytotelmic microhabitats in rainforest canopy in Madagascar. Journal of Crustacean Biology 25: 302-308
Daniels SD, Cumberlidge N, Pérez-Losada M, Marijnissen SAE, Crandall KA. 2006. Evolution of Afrotropical freshwater crab lineages obscured by morphological convergence. Molecular Phylogenetics and Evolution 40: 225-235.

De Man JG. 1901. Description of a new Freshwater Crustacea from the Soudan, followed by some remarks on an allied Species. Proceedings of the Zoological Society 94-104.

Esser LJQ. 2007. The osmoregulatory abilities of freshwater crabs from Thailand (Potamidae and Parathelphusidae) and biogeographical implications. M.Sc. Thesis, Northern Michigan University.

Haig J. 1984. Land and freshwater crabs of the Seychelles and neighbouring islands. In: Stoddart DR ed. Biogeography and Ecology of the Seychelles Islands. The Hague: W. Junk, 124-139.

Kingdon J. 1989. Island Africa. Princeton: New Jersey: Princeton University Press, 1-287.

Klaus S, Schubart C, Brandis D. 2006. Phylogeny, biogeography and a new taxonomy for the Gecarcinucoidea Rathbun, 1904 (Decapoda: Brachyura). Organisms, Diversity and Evolution 6: 199-217.

Latreille PA. 1828. Telphuse et Trichodactyle. In: Latreille PA, Godart JB eds. Encyclopédie Méthodique. Histoire naturelle. Entomologie, ou histoire naturelle des crustacés, des arachnides et des insectes. Paris: Veuve Agasse 10: 561-564, 705.

Milne-Edwards A. 1868. Description de quelques Crustaces nouveaux provenant des voyages de M. Alfred Grandidier a Zanzibar et a Madagascar. Nouvelles Archives du Museum d'Histoire Naturelle, Paris 4: 69-92.

Morris S, van Aardt WJ. 1998. Salt and water relations, and nitrogen excretion, in the amphibious African freshwater crab Potamonautes warreni in water and in air. Journal of Experimental Biology 201: 883-893.

$\mathrm{Ng}$ PKL, Rodriguez G. 1995. Freshwater crabs as poor zoogeographical indicators: a critique of Banarescu (1990). Crustaceana 68: 636-645.

Ng PKL, Takeda M. 1994. Skelosophusa (Crustacea, Decapoda, Brachyura), a new genus of potamonautid freshwater crab from Madagascar, with descriptions of two new species. Bulletin of the Natural Science Museum, Tokyo, Japan, Series A 20: 161-172.

Ng PKL, Tan LWH. 1984. A new freshwater crab, Stoliczia (Johora) tiomanensis n. sp. (Decapoda: Brachyura: Potamidae) from Pulau Tioman, West Malaysia. Malayan Nature Journal, Kuala Lumpur, Malaysia 37(3): 167-174.

Ng PKL, Števčić Z, Pretzmann G. 1995. A revision of the family Deckeniidae Ortmann, 1897 (Crustacea, Decapoda, Brachyura, Potamoidea) from the Seychelles, Indian Ocean. Journal of Natural History 29: 581-600.

Ng PKL, Guinot D, Davie, P. 2008. Systema Brachyuorum: Part I. An annotated checklist of extant Brachyuran crabs of the world. Raffles Bulletin of Zoology 17: 1-286.

Prahl H von. 1983. Hypolobocera gorgonensis sp. nov. (Crustacea: Brachvura: Pseudothelhusidae) un nuevo cangrejo de agua dulce de la Isla de Gorgons. Cespedesia 12: 105-110. 
Rabinowitz PD, Coffin MF, Falvey D. 1983. The separation of Madagascar and Africa. Science 220: 67-69.

Randall JW. 1839. Catalogue of the Crustacea brought by Thomas Nuttall and J. K. Townsend from the West Coast of North America and the new Sandwich Island, with description of such species as are apparently new, among which are included several species of different localities, previously existing in the collection of the Academy. Journal of the Academy of Natural Sciences of Philadelphia 8: 106-147.

Rathbun MJ. 1898. A contribution to a knowledge of the freshwater crabs of America. Proceedings of the U.S. National Museum 21: 507-537.

Rathbun MJ. 1904. Les Crabes d'Eau Douce (Potamonidae). Nouvelles Archives du Muséum d'Histoire Naturelle, Paris 6: 225-312.

Raxworthy CJ, Forstner M, Nussbaum RA. 2002. Chameleon radiation by oceanic dispersal. Nature 415: 784-787.

Reed SK, Cumberlidge N. 2004. Notes on the taxonomy of Potamonautes obesus (A Milne-Edwards, 1868) and Potamonautes calcaratus (Gordon, 1929) (Brachyura: Potamoidea: Potamonautidae) from eastern and southern Africa. Zootaxa 418: 1-20.

Reed SK, Cumberlidge N. 2006a. Foza raimundi, a new genus and species of potamonautid freshwater crab (Crustacea: Decapoda: Potamoidea) from northern Madagascar. Proceedings of the Biological Society of Washington 119: 58-66.

Reed SK, Cumberlidge N. 2006b. Taxonomy and biogeography of the Freshwater crabs of Tanzania, East Africa (Brachyura: Potamoidea: Potamonautidae, Platythelphusidae, Deckeniidae). Zootaxa 1262: 1-139.

Rodríguez G. 1982. Les crabes d'eau douce d'Amerique Famille des Pseudothelphusidae. Faune Tropicale 22, Paris: Office de la Recherche Scientifique d'Outre Mer (Orstom).

Rodríguez G. 1986. Centers of radiation of freshwater crabs in the Neotropics. Crustacean Issues 4: 51-67.

Rodríguez G, López B. 2003. Insular species of Neotropical freshwater crabs (Crustacea: Brachyura). Journal of Natural History 37: 2599-2614.

Rodríguez G, Williams, AB. 1995. Epilobocera wetherbeei, a new species of freshwater crab (Decapoda: Brachyura: Pseudothelphusidae) from Hispaniola. Proceedings of the Biological Society of Washington 108: 76-83.

Shaw J. 1958a. Solute and water balance in the muscle fibres of the East African fresh-water crab, Potamon niloticus (M. Edw.) Journal of Experimental Biology 36: 145-156.

Shaw J. 1958b. Salt and water balance in the East African fresh-water crab, Potamon niloticus (M. Edw.) Journal of Experimental Biology 36: 157-176.

Shy JY, Ng, PKL, Yu HP. 1994. Crabs of the Genus Geothelphusa Stimpson, 1858 (Crustacea: Decapoda Brachyura: Potamidae). Raffles Bulletin of Zoology 42 (4): 781-846.

Storey M, Mahoney JJ, Saunders AD, Duncan RA, Kelley SP, Coffin MF. 1995. Timing of hot spot-related volcanism and the breakup of Madagascar and India. Science 267: 852-855.

Vences M, Vieites DR, Glaw F, Brinkmann H, Kosuch J, Veith M, Meyer A. 2003. Multiple overseas dispersal in amphibians. Proceedings of the Royal Society B 270: 2435-2442.

Vences M, Wanke S, Vieites DR, Branch WR, Glaw F, Meyer A. 2004. Natural colonization or introduction? Phylogeographical relationships and morphological differentiation of house geckos (Hemidactylus) from Madagascar. Biological Journal of the Linnean Society 83: 115-130.

Yeo DCJ, Ng PKL. 2003. Recognition of two subfamilies in the Potamidae Ortmann, 1896 (Brachyura, Potamidae), with a note on the genus Potamon Savigny. Crustaceana 76: 1219-1235

Yeo DCJ, Ng PKL, Cumberlidge N, Magalhaes C, Daniels SR, Campos M. 2008. A global assessment of freshwater crab diversity (Crustacea: Decapoda: Brachyura). In: Balian EV, Lévequè C, Segers H, Martens M, eds. Freshwater Animal Diversity Assessment. Hydrobiologia 595: 275-286.

Poux C, Madsen O, Marquard E, Vieites DR, de Jong WW, Vences M. 2005. Asynchronous colonization of Madagascar by the four endemic clades of primates, tenrecs, carnivores, and rodents as inferred from nuclear genes. Systematic Biology 54: 719-730.

Yoder AD, Nowak M. 2006. Has vicariance or dispersal been the predominant biogeographic force in Madagascar? Annual Review of Ecology, Evolution \& Systematics 37: 405-431.

Yoder AD, Burns MM, Zehr S, Delefosse T, Veron G, Goodman SM, Flynn JJ. 2003. Single origin of Malagasy Carnivora from an African ancestor. Nature 421: 734-737.

Received: 27 February 2008

Accepted: 16 May 2008 
